Research Article

\title{
The Kings of the Sects- "Moulook At-Tawaef"- and their Attitude towards the Almoravid Movement and Their State in the Lands of "Al-Adwah"- Far Morocco
}

\author{
Sahar A.M. Al-Majali, Ph.D.
}

\author{
Associate Professor, Department of Social \& Applied Science, Princess Alia University College, \\ Al-Balqa Applied University, P.O. Box: (144211) Amman (11814) Jordan,
}

\begin{abstract}
This research deals with the attitude of the Sects' kings towards the Almoravid movement and their state in the land of Al-Adwah - "Far Morocco". While dealing with the critical political, social and military conditions of Andalusia and what it was suffering from internal dissensions, partitions and feuds, it also focuses on the disputes between the kings of the sects- "Moulook At-Tawaef"- alongside the loss of security as a result of the recurring attacks by the Christians. At a time when Andalusia was passing through this situation, the Far Moroccan region was witnessing the emergence of a religious movement; called, Al-Morabeteen 'the Almoravids', which was able to establish a vibrant and a strong state in Far Morocco. This state reached its peak during the era of the Muslim Prince, Yusuf Ibn Tashfin.

As a result of the internal conflicts between the Sects' kings; these kings, people and the Fogaha'-the religious men-, sought the help of the Almoravids. However, the relationship between Yusuf Ibn Tashfin and the kings of the sects"Moulook At-Tawaef"- worsened, which ended with the elimination of the kings of the sects- "Moulook At-Tawaef"-and the Almoravids taking control over Andalusia.
\end{abstract}

Keyword: Andalusia, Morocco, the Sects' Kings, Almoravids State

\section{1) Introduction}

\section{Importance of the Study:}

This research attempts to study the attitude of the sects' kings in Andalusia towards the Almoravids' movement and their state in the land of Al-Adwah- "Far Morocco", and the subsequent developments. A study about the attitude of the kings of the sects-"Moulook At-Tawaef"- would be incomplete without referring to the attitude of the popular groups in that era, especially the views of the Islamic jurists, towards the Almoravids.

The fall of Umayyad caliphate in $422 \mathrm{AH} / 1031 \mathrm{AD}$, inaugurated the commencement of an era of the Sects' Kings in Andalusia that entailed emergence of about 22 independent states and each state was headed by an emir as its king. These newly emerged sects were characterized by conditions of fragility, divisiveness and an array of disputes in all aspects of the political, social, economic and military realms, which in itself rendered Andalusia vulnerable to external interference. Inability of the Sects' kings of Andalusia to face the military onslaughts of Alfonso VI made them look towards Morocco, where the Almoravids had established a strong regime under Yusuf Ibn Tashfin. Concurrent requests from some Sects' kings, people's delegations from the border areas and Islamic scholars of Andalusia elicited military support from Yusuf Ibn Tashfin and their joint efforts proved instrumental in defeating the Castilian forces at the decisive battle of Sagrajas
Continuation of tyrannical rule by the Sects' kings over their subjects in the wake their collaboration with the enemy made Islamic scholars approach Yusuf Ibn Tashfin, with the request to return to Andalusia to rid the people from the tyranny and the humiliation of those kings. The resultant impact was the inclusion of all of Andalusia under the Almoravid state by Yusuf Ibn Tashfin in 485 AH/ 1092 AD. Importance of the study lies in its comparative analysis of the attitudes of different strata of post-Umayyad Andalusian society towards the Almoravids and latter's response to the contemporary developments.

\section{Methodology of Study:}

This study is based on the analytical historical approach, which follows the systematic investigation of various sources of information dealing with major themes of the subject under study. AN attempt is made to resent an in-depth analysis of many views contained in the history books and biographies. Reliance has been placed mainly on the Arabic-Islamic sources; however, related biographical books and some other Western and modern references have also been used.

\section{Study Problem:}

The problem of studying the attitude of the Kings of the Sects"Moulook At-Tawaef'- towards the Almoravid movement and their State in the Maghreb is confined to the scarce specialized 
studies which take into account the importance of this subject exclusively, in addition to studying the interrelations between the Sects' kings on the one hand and between them and the Almoravid state on the other.

\section{Study structure:}

The study is distributed as follows:

\section{- Research Abstract in Arabic}

- Research abstract in English

- Keywords

\section{1) Introduction}

1. Study Importance;

2. Study Methodology;

3. Study Problem;

4. Study structure.

1) Era of the Sects' Kings- "Moulook At-Tawaef"- in Andalusia

2) The genesis of the Almoravid movement and their state in Al-Maghreb

1. The first stage

2. The second stage

3. Conclusion

4. References.

\section{2). Era of the Sects' kings- "Moulook At-Tawaef"- in}

\section{Andalusia}

The prominent feature in the history of Andalusia during the fifth century AH or until the year $484 \mathrm{AH} / 1091 \mathrm{AD}$, is the state of political division of the Arab- Islamic state of Andalusia into about 22 states each of them being ruled by a family, owing to which this period is described as the period of States or the kings of the Sects- "Moulook At-Tawaef"-. Some of the most important states were:

1. The state of Bani Hood in Zaragoza;

2. The state of Thi Noon in Toledo;

3. The state of Bani Al-Aftas in Badajoz;

4. The state of Bano Jahour in Cordoba;

5. The state of Bano Abbad in Sevilla;

6. The state of Abdallah bin Blqeen in Granada;

7. The state of Ibn Smadh in Almeria (Ibn Athari 1983: Pt.3:163,185,193; Al-Abbadi, 1971: 465-7).

These Sects or states were living in two constant states of conflicts, which were:

a- The state of internal conflict: These weak states were in a state of internal competition and conflict between each other: starting with the literary and scientific aspects (AlMarzouqi, 1979: 178-9), and ending with the political and military conflict imposed by the ambitions of these Sects' kings. The negative impact of these conflicts was squandering away of national financial, military and human resources. For example, Bano Abbad entered into conflicts with Ibn Smdah and Ibn Rashiq after their "occupation" of the city of Cordoba (Ibn Athari, Pt.3,
1979: 309), in order to extend the assets of their state to include Sevilla, Murcia and Algeciras (Ibid: 259,261), on the one hand, and on the other hand, there was constant conflict between Abdallah Ibn Balqeen and his brother Tamim about the city of Malaga (Ibn Balqeen, 1955: 101).

b- The state of external conflict: It was embodied in the state of conflict between the Sects' Kings with the Frankish Christian kingdoms, which was characterized by either the armed clash sometimes or the formation of alliances and treaties between a state and one of the Christian kingdoms against its neighbors from other Arab Islamic States (Ibn Balqeen, 1955: 30-31). This led to exhausting of these countries' resources against the foreign enemy, and especially after the fall of Toledo (the middle border) and the city of Madinaceli and Guadalajara, Ibn Al-Assal says on this: $O$ people of Andalusia urge your travels for no one resides in it other than that who is mistaken The dress ravels from its edges and I see the dress of the island raveled from the middle (Abd Al-Jaleel, 1979: 12; Ibn Balqeen, 1955: 76; Al-Abaddi, 1971: 72, 471).

Many attempts had been by the Islamic scholars, as part of the external relations of the Sects' states with the lands of $\mathrm{Al}$ Adwah- "the far Morocco" during that period, in order to calm the souls and the preservation of jihad. At the top of these scholars was Abu Al-Waleed Al-Baji (Abd Al-Jaleel, 1979: 1011), especially when the force of the Muslims started declining before the Frankish fighters (Ibn Athari, Pt. 3, 1983: 260-61). In addition to Abu Al-Waleed Al-Baji, there was $A b u$ Hafs Omar Ibn Al-Hussien Al-Hoznie, who had also argued, in addition to others, that unity is the only path which leads to victory (Abd Al-Jaleel, 1979: 10-11).

A conflict had risen between those Islamic jurists calling for Jihad and some of the kings of the Sects- "Moulook AtTawaef"- such as Abdallah Ibn Balqeen and the scholar AlQali'ie ( Ibn Balqeen, 1955: 116), in addition to Al-Mo'tamad the king of Sevillia killing Abu Al-Hafs Ibn Omar (Abd AlJaleel, 1979: 11).

The economic situation during the Sects' Kings era was on decline, especially in the light of the spendthrift habits of the ruling families in the states, and the tribute paid by the Sect Kings to the Franks (Ibid), which led to greatly increasing the taxes and excises (Al-Marzouqi, 1979: 178, 179). As for the urban movement, it had developed at the beginning of the era as a result of the former era, and it started declining with the collapse of the economic situation of the sects (Ibid: 181).

1) The genesis of the Almoravid movement and their state in Morocco

The start of the Almoravid movement was carried out by Yahya Ibn Ibrahim Al-Jadali or Al-Kadali, who along a group set out for Hajj in $427 \mathrm{AH} / 1035 \mathrm{AD}$, and during their return they resided in Kairouan in $440 \mathrm{AH} / 1048 \mathrm{AD}$, and started attending study circles, including the circle of the Maliki school Sheikh of the Maliki doctrine's circle Abu Omran 
Mousa Al-Fasi the Kairouan Judge, who followed the Maliki school (Ibn Al-Khateib, 1956: 226-227; Ibn Abi Dinar,1286: 104-105; Ibn Khaldoun, 1983, Pt. 5: 182; Al-Nowerie,1956: 375-6). When the Sheikh Abu Omran listened to Yahya Ibn Ibrahim Al-Jadali about the situation of his country and the news of his people, then Yahya asked him to assign one of the Islamic scholars with him to impart his people teachings in the religion, guide them and enlighten them with the biography of the Prophet (peace and blessings of Allah be upon him) (Ibn Al-Atheer, 1966, Pt.9: 619; Ibn Al-Khateib, 1956: .227; Ibn Dinar, 1286: 104).

Abdallah Ibn Yassin Al-Jazoulie, who was one of the Jurists of Morocco, was assigned for this mission, and accompanied Yahya to the land of Jadalh, where he was received by the people warmly and generously (Ibn Al-Khateib, 1956: 228; Ibn Khaldoun, Pt. 5., 1983: 183). Abdallah started urging them to avoid the taboos and rejecting what is evil, which weighted on the people of Jadalh (Ibn Khaldoun, 1983: 183; Ibn AlAtheer, Pt. 9, 1966: 619; Al-Nowerie, 1956: 377-8). Thus, he established a juncture for jihad and worship in an island in the river, which is most likely the Niger River (Ibn Khaldoun, 1983: 229), it was also said that it was in the Senegal River (Ibid: 183) with seven men including Yahya Ibn Omar AlImtouni, and after a while the number of those Almoravids stated increasing until it reached about 1,000 men (Ibn Khaldoun, 1983: 183; Ibn Al-Khateib, 1958: 229-230; AlNowerie, 1956: 379). Abdallah Ibn Yassin Al-Jazouli began to impose upon them jihad on behalf of religion, the first of battles was with the tribe of Jadalah, in which about six thousand men were killed, and after that Jadalh entered within the religious and political framework of the Almoravids ( Ibn Al-Khateib, 1956: 230).

Following the death of Abdallah Ibn Yassin in $451 \mathrm{AH} / 1059$ $\mathrm{AD}$, the Almoravids chose Abu Baker Al-Lamtouni as his successor, and he was the one to defeat the Barghawaties. Abu Baker then decided to move to the Sahara to control the issues that were rising in it, so he entrusted his cousin Yusuf Ibn Tashfin with the issue in 452 AH/ 1060 AD (Ibn Khalican, 1968, Pt. 6: 112).

After exerting his control over the Zanata tribes, during his forays in the north, Yusuf Ibn Tashfin then started building the city of Marrakech and fortifying it. He was also able to enter the cities of Fas, Meknes, Tangier and Ceuta (Ibid: 112, 113). Moreover, in $464 \mathrm{AH} / 1071 \mathrm{AD}$, he wrote down the divans, established them and organized the armies, and the country owed him submission. This is what Abu Baker Al- AlLamtouni realized after his last visit from the Sahara, where the latter felt the power and strength of Prince Yusuf, thus he made sure to hand over the matter to the prince Yusuf Ibn Tashfin based on the advice of Yusuf Ibn Tashfin's wife, this was done in 466 AH/ 1073AD. (Ibn Khalican, 1968: 113; AlNowerie, 1956: 379), and this could be said to be the real beginning of Almoravid era, which can be divided into two stages:
There was an apparent contrast between what was happening in Far Morocco ( $A l$-Adwah) and what was happening in Andalusia, for there was the young and powerful Almoravid state, considered to be at the height of its greatness; on the other hand, the Sects' states were living in a state of political rapture and were at the receiving end of powerful hits at the hands of the Christians in Andalusia.

The first contact between the kings of the Sects- "Moulook AtTawaef"- "sedation" and Yusuf Ibn Tashfin took place when Prince Yusuf started thinking of crossing Andalusia, where he started establishing manufacturing-houses for ships and boats said to be prior to $477 \mathrm{AH} / 1087 \mathrm{AD}$ (Al-Maqarri, 1965, Pt.4: 354; Al-Nassiri, Pt. 2, 1956: 35; Ibn Al-Atheer, Pt. 10, 1966: 141).

Establishment of manufacturing-houses for ships and boats along with the control over the city of Ceuta, which represented a transit point for Andalusia, by the Almoravids were alarming developments for the kings of the Sects"Moulook At-Tawaef"-, who regarded it a threat to their thrones (Ibn Al-Abbar, Pt. 2, 1963: 99; Al-Maqri, 1965: 355, 356; Ibn Al- Atheer, Pt 10, 1966: 111, 142). In consultation with Al-Mo'tamad Ibn Abbad, then king of Toledo, the Sects' kings agreed to send gifts and messengers to Yusuf ibn Tashfin, to avoid his 'threat' and entrance to their lands, and their desire foran alliance with him was accepted by Prince Yusuf, as his response was reassuring (ibid.).

The fall of Toledo into the hands of the Christians in $478 \mathrm{AH} /$ $1085 \mathrm{AD}$, raised two important trends, which crystalized two attitudes towards the Almoravids state, which are:

1. The attitude of the general public was impacted by their growing discontent with the kings of the Sects- "Moulook At-Tawaef'-, as well as the state of division and rapture they were living in ( Ibn Al-Khateib, 1956: 242; Ibn Balqeen, 1955: 108). The people of Andalusia wrote to Yusuf Ibn Tashfin, particularly some of the Andalusian Princes, scientists and scholars, urging him to travel and cross to Andalusia to fight the enemy and getting rid of him, promising them that they will be with him as one entity ( Ibn Khaldoun, 1983: 186; Al-Naseri, 1956: 33).

2. The attitude of the kings of the sects- "Moulook AtTawaef'- was impacted by their realization that the fall of the Middle Border, "which includes Toledo, the base of that Border and its work" threatens them all, and that they were not immune to it (Ibn Balqeen, 1955: 101). Therefore, Al-Mo'tammad Ibn Abbad, then the greatest of the Sects kings, decided to cross to Morocco by himself in 479 AH/ 1086 AD, where he met Yusuf Ibn Tashufin in Al-Mahdyah, and apprised the latter about what was happening in Andalusia and the events that threatened the entire entity of Islam, encouraging him to fight and go to jihad against the Christians.

\section{The first stage}


Some historians have opined that that it was actually limited to correspondences and ambassadors exchanged between $A l$ Mo'tamad Ibn Abbad and Ibn Tashfin. Al-Mo'tamad mentioned him in those correspondences using titles such as Amir Al-Muamenen- "The prince of believers", "the champion of the religion". As Yusuf Ibn Tashfin had prepared for the idea of crossing to Andalusia with a number of men and weapons to be at the height of readiness at the right time (AlMarrakishi, 1949: 131; Ibn Abi Dinar, 1286: 108).

In addition to the visit of Al-Mo'tamad and the promise of Yusuf Ibn Tashfin in supporting the Andalusians in their ordeal, the fall of Toledo, and the Andalusian Islamic scholars' quest for eliciting Almoravid support were some of the qualitative developments that had prepared the conditions to formally call the Almoravids to cross to Andalusia. Most resources point out that the main reason in summoning Yusuf Ibn Tashfin was the result of the dispute between $A l$ Mo'tamad Ibn Abbad and Alfonso VI, which is illustrated by the resources in various forms.

As the reason behind the dispute was the delay of $A l$ Mo'tamad Ibn Abbad in paying tribute, so Alfonso VI wanted to add on it, and Al-Mu'tamid refused that (Al-Maqriri, 1965: 357- 358; Ibn Al-Atheer, Pt. 10, 1966: 142-143). Delaying tactics by Al-Mo'tamad to pay promised money to the delegation led by Ibn Shaleb Al-Yahoudi on behalf of Alfonso VI irked Ibn Shaleb who then talked rudely with $A l$ Mo'tammad, who then killed him and arrested the knights who were with him, thereby leading to rapid unfolding of developments (Ibn Al-Atheer, Pt. 10, 1966: 142-143; AlNowerie, 1956: 158; Al-Maqarri, 1965: 356 \& 358).

Ibn Balqeen points out that the reason behind the conflict between Alfonso VI and Al-Mo'tamad Ibn Abbad, was that Alfonso, after his conquest of Toledo, sent a messenger with a great group of five hundred knights, demanding the tribute from Al-Mo'tamad. The messenger refused the tribute because he was suspicious of its gold, he also asked him to give up all of the castles and forts in the mountains while keeping the flat ground for the Muslims, Al-Mo'tamad refused to give them up, and ordered the killing of the five hundred knights, and only kept three knights; who returned to Alfonso VI and told him what happened (Ibn Balqeen, 1955: 101-102). The reactions of Al-Mo'tamad Ibn Abbad against Alfonso were not in vain, because he knew that ibn Tashfin had best prepared for Jihad in Andalusia.

It is noteworthy that the official call of Ibn Tashfin to Jihad in Andalusia after the conflict of Ibn Abbad with Alfonso VI had two main dimensions:

The first dimension was popular; this dimension took place after the delegation accident, which took a serious turn. After the Sheikhs of Cordoba heard the news of the delegation and the escalation of the conflict with the Castilian king Alfonso $V I$ and the power of the Franks and the rapture of Andalusia, they sent to Abdallah Ibn Mohammad Ibn Adham one of Cordoba's judges, to discuss with him about the situation of

The International Journal of Social Sciences and Humanities Invention, vol. 5, Issue 01, January, 2018 the Muslims, and suggested to call upon the Arabs of Africa "the Hilalites", but he instilled fear in them about the Arabs of Africa and instead suggested to call the Almoravids (Ibn AlAtheer, Pt .10, 1966: 151-152; Al-Nowerie, 1956: 158; AlMaqarri, Pt.4, 1965: 36, 361). This proves that the judge Abdallah Ibn Mohammad Ibn Adham was secretly corresponding with the Almoravids, or that he had connections with them; therefore, the Sheiks , after the approbation of what he suggested, asked him to write to Ibn Tashfin, and in the meantime Ibn Alabbad happened upon them, so the Judge told him about what had been conversed about and thus $\mathrm{Al}$ Mo'tamad Ibn Abbad adopted him as one of his messengers to Yusuf Ibn Tashfin (Al-Nowerie, 1965: 158-159; Al-Maqarri, 1965: 360-361; Al-Naseri, 1956: 39-40).

As for the other dimension pertaining to invitation, is the formal dimension, and this is what had been pointed to by various narrations. It seems that a meeting was held under the leadership of Ibn Abbad in the presence of some of the Sects' kings in Andalusia to discuss the issue of the invitation to Yusuf ibn Tashfin. When those kings noticed the determined insistence of Ibn Abbad on his invitation plea, they tried to discourage him by intimidating him about the Almoravids who could "overthrow them from their posts" (Ibn Al-Abbar, 1963: 28; Ibn Khalican, 1983: 115; Al-Naseri, 1956: 38-39). However, he answered them with his known sentence "the herding of camels is better than the herding of pigs" (Ibn Khalican, 1983: 115-116; Al-Maqarri, 1965: 539).

It appears that the tendency towards not summoning the Almoravids was crystalized under the state of Bano Al-Abbad fearing for their interests, to which Al-Mo'tamad had answered by saying that the help of Ibn Tashfin pleases Allah and that his cooperation with Alfonso angers Allah, and thus the kings of Andalusia agreed collectively on summoning the Almoravids for Jihad (Ibn Khaldoun, 1983: 186; Al-Naseri, 1956: 40). Subsequently, Al-Mu'tamid formed a delegation comprising a number of judges -the judge of the city of Badajoz, the judge of Grenada and the judge of Sevilla (Ibn Balqeen, 1955: 103; Ibn Khaldoun, 1983: 184). A minister named Abu Baker Mohammad Ibn Al-Waleed Ahmad Ibn Abdallah Ibn Zaydoon, was also included in the delegation in order to hold the royal agreements, while the judges were to encourage the Prince of Muslims to jihad (Ibn Khaldoun, 1983: 186; Al-Naseri, 1956: 34).

Yusuf Ibn Tashfin formed a general but accurate idea about the prevalent situation of Andalusia and his future strategy for jihadi actions. Inputs for Ibn Tashfin's general view came from scholars' correspondences with him, feedback from people's delegations of the people of the Borders who called him for Jihad, as well as his meeting with Ibn Abbad. Tamim Ibn Balqeen, the owner of Malaga, held meetings with Ibn Tashfin in which the former begged him to intervene to help restore his right form his brother Abdallah Ibn Balqeen, the owner of Granada (Ibn Balqeen, 1955: 245-246).

All these inputs led Ibn Tashfin to formulate his comprehensive strategy about Andalusia and its internal 
conflicts. He also consulted his companions who were united on the victory for the Muslims in Andalusia from the Franks, provided that the Algeciras be the center for his forces and a fortified base for them; based on the advice of the Andalusian scholar Abd Al-Rahman Ibn Subat (Ibn Al-Khateib, 1956: 245246). The negotiations were conducted between Yusuf Ibn Tashfin and the Andalusian delegations, where Ibn Tashfin decided to cross over to Andalusia (Ibn Al-Abbar, 1963: 98; Al-Maqarri, 1965: 359-360).

Having entered Andalusia in 479 AH/ 1086AD, Yusuf Ibn Tashfin headed towards Sevilla, where he met the Andalusian Sects' kings (Ibn Balqeen, 1955: 103; Al-Naseri, 1956: 48), all of whom were eager for jihad and rejoiced in it (Al- Naseri, 1956: 49; Ibn Balqeen, 1955: 103). They arrived at a location close to the town of Badajoz called Sagrajas, where the battle known as the Sagrajas took place on Friday, 13 of Ramadan $479 \mathrm{AH} / 1086 \mathrm{AD}$, in which the Almoravids' army won with the coalition of the Arab Islamic forces against the army of Castilian king Alfonso VI. Undoubtedly, the resources differ on the date of the battle of Sagrajas, but the most probable date is what has been mentioned in this body as cited by some Arabic authors (Ibn Balqeen, 1955: 105; Al-Naseri, 1956: 4445; Ibn Al-Atheer, Pt.8, 1966: 142).

In the aftermath of the Arabian- Islamic victory in the battle against the armies of Alfonso VI, Yusuf ibn Tashufin in his meeting with the kings of the Sects- "Moulook At-Tawaef""Al-Fitnah", tried to settle the conflicts between them by stressing that their continued victory and resilience in the face of the Franks could only happen through the purity of faith and their consensus on unity (Ibn Balqeen, 1955: 105-106 ). Thereafter, Yusuf Ibn Tashufin returned to Morocco in 480 AH/ 1087 AD.

\section{The second stage}

In the aftermath of his defeat in the battle of Sagrajas, the Castilian king Alfonso VI having returned to his territory, ordered his military officers to tighten the pressure on the cities of Lorca and Murcia in retaliation of Al-Mo'tamad Ibn Abbad the owner of Sevilla, for calling the Almoravids to Andalusia. While calling upon his allies to raid the borders of the Muslim sects' cities, the forces of Alfonso VI and his allies caused destruction and havoc in the Islamic regions, especially in the cities near the fort of Aledo, such as Valencia, Murcia, Lorca and Baza (Al-Naseri, 1956: 51). This led Al-Mo'tamad to call Yusuf Ibn Tashfin to cross once again to Andalusia to rescue the besieged kings of the Sects (Ibn Al-Khateib, 1956: 247; Ibn Balqeen, 1955: 108; Al-Naseri, 1956: 51).

Having arrived in Andalusia in 481 AH/ 1088 AD, Yusuf met with Al-Mo'tamad Ibn Abbad along with other sect rulers of Granada, Almeria and Malaga, and they together marched towards the fort of Aledo, and besieged it for a moth without being able to get into it because of fort's strong defences. Failure of the powerful and various military siege tools to break in, led Yusuf Ibn Tashfin and Al-Mo'tamad Ibn Abbad to realize that the fort would not fall unless the supplies were cut off. However, they decided to continue the siege no matter how long it could take.

In the meanwhile, the unexpected happened when Ibn Abbad complained to Yusuf Ibn Tashfin, accusing Ibn Rashiq of taking Murcia from him by force and covertly collaborating with the Castilian king. On the advice of his scholars, Yusuf ordered one of his officers to bind Ibn Rashiq to be delivered Ibn Abbad provided that the latter would not kill him. Annoyed over these developments, Ibn Rashiq's army withdrew from the siege, and cut off the city of Murcia supplies from the Muslim army, which disrupted the situation of the Muslim camp.

In his bid to rescue those rapped inside the fort in the wake of prolonged siege, king Alfonso VI found a large number of dead among the trapped inside the fort, he then destroyed and burnt it (Ibn Al-Khateib, 1956: 247; Al-Naseri, 1956: 52). The growing signs of fatigue having entered the hearts of the Sects' kings encouraged Yusuf Ibn Tashfin to end the siege (Ibn Abi Dinar, 1286: 108-109; Ibn Al-Khateib, 1956: 247; Ibn Khalican, 1968: 128). In the aftermath of the dissolution of the siege, Yusuf Ibn Tashfin, while returning to Morocco in $481 \mathrm{AH} / 1088 \mathrm{AD}$, he left some of the Almoravid forces under the leadership of Mohammad Ibn Tashfin (Ibn Al-Khateib, 1956: 246; Al-Naseri, 1956: 52).

Undoubtedly, the sources don't explain the reasons behind the return of Ibn Tashfin to Morocco after the siege of Aledo; nevertheless, Ibn Atharie hinted in his book Al-Bayan AlMughrab mentioned that ibn Tashfin, during his siege of Aledo had heard talk from the kings of Andalusia, which had turned his heart against them and especially against Abdallah Ibn Balqeen the King of Granada (Ibn Balqeen, 1955: 109).

After the return of Yusuf Ibn Tashfin to Morocco, it became apparent that the gains of the battle of Sagrajas were waning as Alfonso returned to impose tribute on the sects' cities, and Abdallah Ibn Balqeen of Granada had paid what he had owed from tribute (Ibn Khalican, 1983: 128; Ibn Balqeen, 1955: 115-116). There is doubt that the Sects' kings had begun to feel the change in Ibn Tashfin's attitude towards them, thus they started fortifying their respective territories to face him for they feared that he would occupy it, in addition to making treaties through the secret correspondences between them and the king of Castile Alfonso VI, to be their supporter against Ibn Tashfin if he entered Andalusia.

Getting wind of this, Ibn Tashfin (Hatamleh, 2000: 544; AlTawati, 1967: 95), therefore, decided to start overthrowing the kings of the sects and for this reason, he crossed to Andalusia for the third time in $483 \mathrm{AH} / 1090 \mathrm{AD}$, on an initiative of his own and not at the request of the Sects' kings as had been in previous two cases, and he faced the king of Castile Alfonso $V I$ by himself, for the following reasons:

1- The internal and deep-rooted conflicts and disputes between the kings of the sects- "Moulook At-Tawaef"-, as attempts of Yusuf Ibn Tashfin had failed to end them. 
Sahar A.M. Al-Majali et al / The Kings of the Sects- "Moulook At-Tawaef"- and their Attitude towards the Almoravid Movement and Their State in the Lands of "Al-Adwah"- Far Morocco

2- The kings of the Sects- "Moulook At-Tawaef"- cut off the aids of supplies and equipment's to the Almoravid forces in Andalusia, which weakened their status, even though those forces have had made sacrifices in order to turn the danger off of the Muslim lands in Andalusia (Ibn Atharie, Pt. 4, 1983: 143; Ibn Al-Atheer, Pt. 8, 1966: 143).

Ibn Tashfin headed to Toledo to fight Alfonso VI, although he did not fight it protesting its immunity, so he left it and headed to the city of Granada and besieged it for two months until it surrendered to him and then he took over the city of Malaga from its owner-King Tamim Ibn Balqeen (Ibn Atharie, Pt 4, 1983: 143-144; Al- Naseri, 1956: 53). Ibn Tashfin's attitude for other Sects' kings was different, as he refused to welcome both Al-Mo'tamad Ibn Abbad and Al-Motawakel Ibn Al-Aftas when they came to congratulate him with the ownership of Granada and it was at that juncture that they realized that the end of the kings of the Sects- "Moulook At-Tawaef"- was imminent (Ibn Al-Khateib, 1956: 247; Ibn Khalican, 1968: 128-129).

Ibn Tashfin became comfortable with the reasons which allowed him to overthrow the Kings of the Sects- "Moulook At-Tawaef"- and take over their cities, and these reasons were reinforced by following developments:

1. The referendum of the scholars of Andalusia and the general public, as the Islamic jurists, including $\mathrm{Abu} J a$ 'far Ibn Al-Qalai' the judge of Cordoba, condemned the corruption of - the kings of the sects "Moulook AtTawaef"-, their malice and deception.

2. Obtaining the fatwas of the Orient jurists, such as $A l$ Tartoshi and Al-Ghazali, whose fatwas had reached him in $493 \mathrm{AH} / 1099 \mathrm{AD}$, by then he had already begun overthrowing the Sects' Kings since 483 AH/ 1090 AD. (Ibn Khalican, 1968: 128; Al-Naseri, 1956: 53).

Ibn Tashfin returned to Al-Maghreb, and left his leader Saier Ibn Abi Baker Al-Latmouni as a guardian of Andalusia, and had entrusted all of its matters to him. Here comes the role of the narration which points out that even though Saier Ibn Abi Baker had sent message to Yusuf Ibn Tashfin telling him about the condition of the fighters in the borders and their hard-living conditions in comparison to the quality of live among the Sects' Kings, yet Yusuf allowed the kings of the sects- "Moulook At-Tawaef"- to take what they owned (AlNaseri, 1956: 53; Hatamleh, 2000: 544). In 484 AH/ 1091 $\mathrm{AD}$, Ibn Tashfin began issuing his orders to his leaders in Andalusia to seize Sects' kingdoms; the first of the kingdoms which was seized by the Almoravids after Granada and Malaga, was the city of Cordoba (Ibn Khalican, 1968: 129; Al-Marrakishi, 1949: 42).

Saier Ibn Abi Baker sieged Sevilla from Al-Mo'tamad Ibn Abbad, after the latter tried to correspond with Alfonso VI asking him for help, and he refused. In 485 AH/ 1092 AD, the Almoravids seized the city of Badajoz, and killed $A l$ Motawakel Ibn Al-Aftas, and his sons, Al-Fadel and Al-Abbas (Ibn Al-Atheer, Pt. 8, 1966: 155), and with this the Kings of the Sects- "Moulook At-Tawaef"- Al-Fetnah had either ended or dead, such as what happened to Bani Al-Aftas, or exiled to Morocco and other kings of Al-Fetnah (Al-Naseri, 1956: 55; Ibn Athari, Pt 4, 1983: 143- 144).

Almost the entire Andalusian Peninsula was subjected to the control of the Almoravids with the exception of the city of Zaragoza which was owned by Bani Hood, which fell into the hands of the Almoravids in the year 503 AH/ 1109 AD ( AlNaseri, 1956: 55; Ibn Athari, Pt. 4, 1983: 143-144). Thus, Andalusia became under the rule of the Almoravids under the leadership of Yusuf Ibn Tashfin, starting from the town of IFraga in the east, to the city of Lisbonna on the west of the Atlantic Ocean (Al-Naseri, 1956: 56-57).

\section{2) Conclusion}

The age of the kings of the Sects- "Moulook At-Tawaef"-, spanning over more than eight decades, was characterized by conditions of political, economic and social disintegration, as these states fought between themselves on the familial leadership. The leadership system, based on inheritance, often led to internal conflicts within the members of the same family, especially when trying to divide the positions of the state between more than one of the ruler's sons. The kings of the sects- "Moulook At-Tawaef"- were living in a state of indulgence and luxury, while the rest of the subjects were living in a degraded and bad economic situation - a sufficient incentive to fuel people's discontent against the sects' kingsAl-Fetnah.

Emergence of Almoravid movement as a religious movement occurred at a time when Andalusia was riddled with internal dissensions and conflicts between the Kings of the Sects"Moulook At-Tawaef"-. The Almoravid movement established a state built on sound religious and political foundations, which spread to include Far Morocco 'Maghreb'. This state had reached its peak in the reign of Yusuf Ibn Tashfin.

After the fall of Toledo in 478 AH/ 1085 AD, the Kings of the Sects- "Moulook At-Tawaef"- sought the help of this powerful state. The attempts of Al-Mo'tamad Ibn Abbad to seek help from the Almoravid leader Ibn Tashfin for Jihad against the Christians coincided with the efforts of the people of the borders and the scholars from Andalusia to elicit similar support from Ibn Tashufin. Even though Al-Mo'tamad ibn Abbad refused the arguments, made by the Sects' kings, designed to deter him from seeking help from the Almoravids, yet his position was honorable and timely, and Yusuf Ibn Tashfin entered Andalusia for the first time (479 AH/ 1086 $\mathrm{AD})$

Ibn Tashfin was able to achieve an overwhelming victory, with the help of his own strong army, in addition to the Andalusian forces, against the Christians led by the Castilian king Alfonso VI in the battle Sagrajas in 479 AH/ 1086 AD. Concurrently, Ibn Tashfin also came to know about the unbelievable extravagant and luxurious life-styles of the kings of Andalusia, not to mention the internal conflicts happening among them. 
The siege of the fortress of Aledo by Ibn Tashfin, after he crossed to Andalusia in $481 \mathrm{AH} / 1088 \mathrm{AD}$, had an important influence in turning his attitude towards the Sects' Kings, and he had started thinking clearly as to how to overthrow and get rid of them. However, in order to obtain legitimacy for his decision, he depended on the fatwas of the scholars and the general public of Andalusia, including $\mathrm{Abu} J \mathrm{Ja}^{\prime} \mathrm{far} \mathrm{Ibn} \mathrm{Al}$ Qili'e the judge of Cordoba, in addition to the fatwas of the Oriental Jurists such as Al-Tartoshi and Al-Ghazalie. He began overthrowing the kings of the sects- "Moulook At-Tawaef"since $483 \mathrm{AH} / 1090 \mathrm{AD}$. Later on; he was able to subject Andalusia to the influence of the Almoravid state under his leadership.

\section{3) References:}

1. Abd Al-Jaleel, Mohammad (1979), How did the Andalusian Fogaha- Religious Scholars- helped Yusuf Ibn Tashfin in overthrowing the kings of the Sects"Moulook At-Tawaef"-, The works of the $4^{\text {th }}$ SpanishTunisian summit. Madrid.

2. Al-Abbadi, Ahmad Mukhtar (1971), In the History of Morocco and Andalusia. Al- Nahda Al-Arabiah House for printing and publishing, Beirut- Lebanon.

3. Al-Maqarri, Shihab Al-Deen Ahmad Ibn Mohammad AlTalmasani (1965), (Died, 1041AD), Nafh At-Teeb fi Ghoson Al-Andalouse Al-Rateeb, Pt 4, Investigated by Ihsan Abbas, Sader House for Printing and Publishing. Beirut.

4. Al-Marrakishi, Muhie Al-Deen Abed Al-Wahed Ibn Ali (1949), (Died, 620 AH/ 1224 AD), Al-Mu'jab fi Talkhees Akhbar Al-Maghreb- The Admirer in Summing up the News of Morocco-, (from the conquest of Andalusia and until the end of the Al-Mouwahedeen era), revised by Mohammad Saied Al-Aryan and Mohammad Al-Arabi Al-Alami, Al-A'Stiqama printing press, Cairo. $1^{\text {st }} \mathrm{ed}$.

5. Al-Marzouqi, Riyad (1979), Features of the Andalusian Civilization in the Sects' kings Era, The works of the $4^{\text {th }}$ Spanish- Tunisian Summit, Madrid.

6. Al-Naseri, Abu Al-Abbas Ahmad Ibn Khalid (1956), The Investigation of the Far Morocco Countries News, Part 2, revised by Prof. Ja'far Al-Naseri and Mohammad AlNaseri. Dar Al-Ketab press, Casablanca.

7. Al-Nowerie, Shihab Ad-Deen Ahmad Ibn Abdel Wahab (1956), (Died, 733 AH), The History of the Islamic Maghreb, from the book of, Nihayat Al-Arab fi Fonoon Al-Adab, - the End of the Arabs in Literature Arts-, Investigated by Mustafa Abu Fief, The Moroccan publishing house, Casablanca.

8. Al-Tawati, Abd Al-Kareem (1967), The Tragedy of the 21. collapse of the Arab Presence in Andalusia, $1^{\text {st }}$ ed., Rahsad Library, Casablanca.
9. Hatamleh. Mohammad Abo (2000), Andalusia, History, Civilization and Tribulation, Al-Dustour commercial Printing Press, Amman-Jordan.

10. Ibn Al-Atheer, Al-Sheikh Ezz Al-Deen Abu AL-Hassan Ali Ibn Abi Al-Karam, and Mohammad Ibin Mohammad Ibin Abdul Kareem bin Wahed Ash-Sheibani (1966), AlKamel in History, Part 8, Sader house for printing and publishing. Beirut.

11. - (1966), Al-Kamel in History, Part 9, Sader house for printing and publishing. Beirut.

12. - (1966), Al-Kamel in History, Part 10, Sader house for printing and publishing. Beirut.

13. Ibin Abi Dinar, Abi Abdallah Al-Sheikh Mohammad Ibn Abi Al-Qasim Al-Reieni Al-Qairawani (1286), Al-Monies in the news of Tunisia and Africa, $1^{\text {st }}$ ed., The Tunisian State Press.

14. Ibn Al-Abbar, Abu Abdallah Mohammad Ibn Abdallah Ibn Abi Baker (1963), Al- Hillati Al-Ssayra', revised by Hussein Mu'nes, Part 2, The Arabian Company for Printing and Publishing, Cairo.

15. Ibn Al-Khateib, The Minister, Lisan Al-Deen Abu Abdallah Mohammad As-Salmani (1956), (Died, 776 A.H./ 1374 A.D., The History of Islamic Spain (Or the book of the works of the famous who had been assigned before puberty from the Kings of Islam), Investigated and commented on by Levy Provencal, $2^{\text {nd }}$ ed., Al-Makshouf House, Beirut.

16. Ibn Athari Al-Marrakishi, Abu Abbas Ahmad bin Mohammad (1983), (Died. 695 AH/ 1295 AD), Al-Bayan Al-Mughrab in the news of Andalusia and Morocco, Pt 3, $3^{\text {rd }}$ ed, Investigated by: Levy Provincial, J.S Collan, House of Culture, Beirut,

17. - (1983); Bayan Al-Mughrab in the news of Andalusia and Morocco, Pt. 4, $3^{\text {rd }}$ ed, Investigated by: Levy Provincial, J.S Collan, House of Culture, Beirut.

18. Ibn Balqeen, Abdallah (1955), Al-Tibian, Investigated by: Levy Provencal. Al-Ma'ref Egyptian House. Cairo.

19. Ibn Khaldoun, Abd Al-Rahman (1983), (Died, 808 AH/ 1408 AD), The History of Ibn Khaldoun, "The book of Lessons, and the Diwan of the Beginner and the News in the History of the Arab, Barbar and their Contemporaries of the Great Sultans", Part 5, The Lebanese book house for printing and publishing, Beirut.

20. Ibn Khalican, Ahmad Ibn Mohammad Ibn Abi Baker (1968), The Deaths of the Notables and the News of the People at the Time, Part 6, Investigated by Ihsan Abbas, Sader House for Printing and Publishing. Beirut.

Mahmoud, Hassan Ahmad, The Rise of the Almoravids State, a Bright Page in the History of AL-Maghreb in the Middle Ages, The Arab Though House. Cairo, Egypt, (D.L). 